\title{
Identifying areas prone to coastal hypoxia - the role of topography
}

\author{
Elina A. Virtanen ${ }^{1,2}$, Alf Norkko ${ }^{3,4}$, Antonia Nyström Sandman ${ }^{5}$, and Markku Viitasalo ${ }^{1}$ \\ ${ }^{1}$ Marine Research Centre, Finnish Environment Institute, Helsinki, 00790, Finland \\ ${ }^{2}$ Department of Geosciences and Geography, University of Helsinki, Helsinki, 00014, Finland \\ ${ }^{3}$ Tvärminne Zoological Station, University of Helsinki, Hanko, 10900, Finland \\ ${ }^{4}$ Baltic Sea Centre, Stockholm University, Stockholm, 10691, Sweden \\ ${ }^{5}$ AquaBiota Water Research, Stockholm, 11550, Sweden
}

Correspondence: Elina A. Virtanen (elina.a.virtanen@environment.fi)

Received: 10 April 2019 - Discussion started: 16 April 2019

Revised: 25 June 2019 - Accepted: 30 July 2019 - Published: 27 August 2019

\begin{abstract}
Hypoxia is an increasing problem in marine ecosystems around the world. While major advances have been made in our understanding of the drivers of hypoxia, challenges remain in describing oxygen dynamics in coastal regions. The complexity of many coastal areas and lack of detailed in situ data have hindered the development of models describing oxygen dynamics at a sufficient spatial resolution for efficient management actions to take place. It is well known that the enclosed nature of seafloors and reduced water mixing facilitates hypoxia formation, but the degree to which topography contributes to hypoxia formation and small-scale variability of coastal hypoxia has not been previously quantified. We developed simple proxies of seafloor heterogeneity and modeled oxygen deficiency in complex coastal areas in the northern Baltic Sea. According to our models, topographical parameters alone explained $\sim 80 \%$ of hypoxia occurrences. The models also revealed that less than $25 \%$ of the studied seascapes were prone to hypoxia during late summer (August-September). However, large variation existed in the spatial and temporal patterns of hypoxia, as certain areas were prone to occasional severe hypoxia $\left(\mathrm{O}_{2}<2 \mathrm{mg} \mathrm{L}^{-1}\right)$, while others were more susceptible to recurrent moderate hypoxia $\left(\mathrm{O}_{2}<4.6 \mathrm{mg} \mathrm{L}^{-1}\right)$. Areas identified as problematic in our study were characterized by low exposure to wave forcing, high topographic shelter from surrounding areas and isolation from the open sea, all contributing to longer water residence times in seabed depressions. Deviations from this topographical background are probably caused by strong currents or high nutrient loading, thus improving or worsening oxygen status, respectively. In some areas, connectivity with adjacent deeper basins may also in-
\end{abstract}

fluence coastal oxygen dynamics. Developed models could boost the performance of biogeochemical models, aid developing nutrient abatement measures and pinpoint areas where management actions are most urgently needed.

\section{Introduction}

Hypoxia is a key stressor of marine environments, occurring in over 400 physically diverse marine ecosystems worldwide (Diaz and Rosenberg, 1995b, 2008; Conley et al., 2009). Declining oxygen levels have been recorded in fjords, estuaries, and in coastal and open-sea areas, such as the Chesapeake Bay, Gulf of Mexico, Japan Sea, Baltic Sea and the Black Sea (Gilbert et al., 2010; Carstensen et al., 2014). It is clear that our oceans are losing their breath, and recent projections indicate that anoxic zones devoid of higher life will be increasing in the forthcoming decades (Frölicher et al., 2009; Meier et al., 2011a, 2012a), with severe consequences for marine ecosystems (Breitburg et al., 2018).

The lack of oxygen alters the structure and functioning of benthic communities (Nilsson and Rosenberg, 2000; Gray et al., 2002; Karlson et al., 2002; Valanko et al., 2015), disrupts bioturbation activities (Timmermann et al., 2012; Villnas et al., 2012, 2013; Norkko et al., 2015), changes predator-prey relationships (Eriksson et al., 2005) and may lead to mass mortalities of benthic animals (Vaquer-Sunyer and Duarte, 2008). Hypoxia does not only affect organisms of the seafloor, but also influences biogeochemical cycling and benthic-pelagic coupling (Gammal et al., 2017). Нypoxia can increase releases of nutrients from the sediment 
and thus promote planktonic primary production and sedimentation, which in turn leads to enhanced microbial consumption of oxygen (Conley et al., 2002; Kemp et al., 2009; Middelburg and Levin, 2009). This creates a self-sustaining process, often referred to as the "vicious circle of eutrophication" (Vahtera et al., 2007), which may hamper the effects of nutrient abatement measures.

Biogeochemical processes contributing to hypoxia formation are well known. Factors affecting the development of hypoxia are usually associated with the production of organic matter, level of microbial activity and physical conditions creating stratification and limited exchange or mixing of water masses (Conley et al., 2009, 2011; Rabalais et al., 2010; Fennel and Testa, 2019). Coastal hypoxia is common in areas with moderate or high anthropogenic nutrient loading, high primary productivity and complex seabed topography limiting lateral movement of the water. Shallow-water hypoxia is often seasonal. It is associated with warming water temperatures and enhanced microbial processes and oxygen demand (Buzzelli et al., 2002; Conley et al., 2011; Caballero-Alfonso et al., 2015; van Helmond et al., 2017).

Projecting patterns and spatial and temporal variability of hypoxia is necessary for developing effective management actions. Thus three-dimensional coupled hydrodynamicbiogeochemical models have been created for several sea areas around the world, such as the Gulf of Mexico (Fennel et al., 2011, 2016), Chesapeake Bay (Scully, 2013, 2016; Testa et al., 2014), the North Sea (Hordoir, 2018) and the Baltic Sea (Eilola et al., 2009, 2011; Meier et al., 2011a, 2012a, b). These models simulate various oceanographic, biogeochemical, and biological processes using atmospheric and climatic forcing and information on nutrient loading from rivers. While such models are useful for studying processes at the scale of kilometers, and aid in defining hypoxia abatement at the basin scale, their horizontal resolution is too coarse (often 1-2 nmi, nautical miles) for accurately describing processes in coastal areas. Lack of detailed data on water depth, currents, nutrient loads, stratification and local distribution of freshwater discharges (Breitburg et al., 2018) (not to mention computational limitations) usually prevents the application of biogeochemical models developed to large geographical areas at finer horizontal resolutions $(<100 \mathrm{~m})$. Understanding spatial variability of hypoxia in topographically complex coastal environments has therefore been impeded by the lack of useful methods and systematic, good-quality data (Diaz and Rosenberg, 2008; Rabalais et al., 2010; Stramma et al., 2012). Finding alternative ways to pinpoint areas prone to coastal hypoxia could facilitate the management and determination of efficient local eutrophication abatement measures.

It is widely recognized that the semienclosed nature of the seafloors, and associated limited water exchange, is a significant factor in the formation of hypoxia in coastal waters (Diaz and Rosenberg, 1995a; Virtasalo et al., 2005; Rabalais et al., 2010; Conley et al., 2011). However, to deter- mine the degree to which seascape structure restricting water movement contributes to hypoxia formation has not been quantified. Analytical and theoretical frameworks developed specifically for terrestrial environments, such as landscape heterogeneity or patchiness, are analogous in marine environments and are equally useful for evaluating links between ecological functions and spatial patterns in a marine context. We tested how a large fraction of hypoxia occurrences could be explained only by the structural complexity of seascapes, without knowledge on hydrographical or biogeochemical parameters. We adopted techniques and metrics from landscape ecology and transferred them to the marine environment, and we (1) examined if spatial patterns in seascapes can explain the distribution of hypoxia, (2) defined the relative contribution of seascape structure to hypoxia formation and (3) estimated the potential ranges of hypoxic seafloors in coastal areas. To achieve this, we concentrated on extremely heterogeneous and complex archipelago areas in the northern Baltic Sea, where coastal hypoxia is a common and an increasing problem (Conley et al., 2011; Caballero-Alfonso et al., 2015).

\section{Data and methods}

\subsection{Study area}

The studied area covers the central northern Baltic Sea coastal rim, $23500 \mathrm{~km}^{2}$ of Finnish territorial waters from the Bothnian Bay to the eastern Gulf of Finland and $5100 \mathrm{~km}^{2}$ of Swedish territorial waters in the Stockholm archipelago in the Baltic Proper. Oxygen dynamics in the deeper areas of the Gulf of Finland and Stockholm archipelago are strongly affected by oceanography and biogeochemistry of the central Baltic Proper, not reflecting the dynamics of coastal hypoxia (Laine et al., 1997), and were therefore excluded from this study. The outer archipelago of Finland is relatively exposed with various sediment and bottom habitat types, while the inner archipelago is more complex and shallower, but maintains a higher diversity of benthic habitats and sediment types (Valanko et al., 2015). The inner archipelago of Stockholm is an equally complex archipelago area, with a large number of islands, straits and coves. Freshwater outflow from Lake Mälaren creates an estuarine environment where freshwater meets the more saline water in the Baltic Proper.

In order to evaluate differences in oxygen deficiency between coastal areas, the study area was divided into five regions as defined by the EU Water Framework Directive (2000/60/EC) (WFD, 2000): the Archipelago Sea (AS), the eastern Gulf of Finland (EGoF), the Gulf of Bothnia (GoB), the Stockholm archipelago (SA) and the western Gulf of Finland (WGoF) (Fig. 1). Small skerries and sheltered bays characterize AS, EGoF and WGoF, whereas the narrower band of islands forms relatively exposed shores in GoB. Deep, elongated channels of bedrock fractures can reach depths of over 


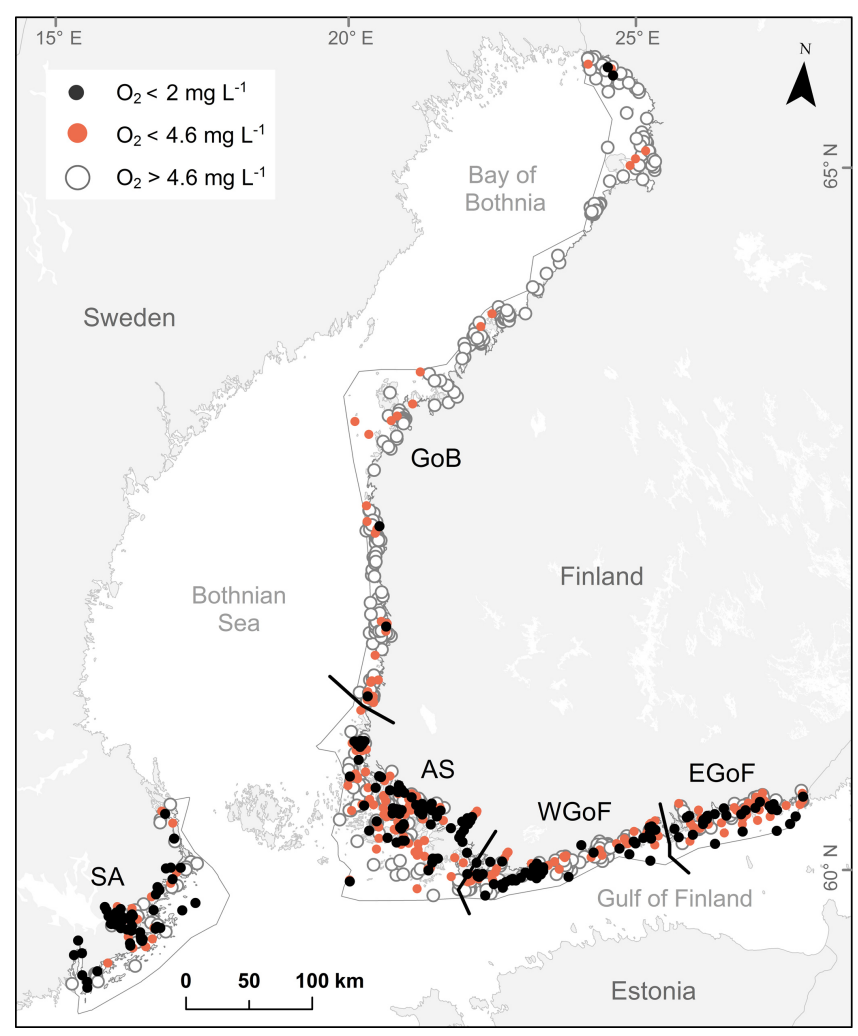

Figure 1. Study areas in Finland: AS - Archipelago Sea, WGoF - western Gulf of Finland, EGoF - eastern Gulf of Finland, and GoB - Gulf of Bothnia. Study area in Sweden: SA - Stockholm archipelago. Orange dots represent moderately hypoxic sites $\left(\mathrm{O}_{2}<4.6 \mathrm{mg} \mathrm{L}^{-1}\right)$, black dots severely hypoxic sites $\left(\mathrm{O}_{2}<2 \mathrm{mg} \mathrm{L}^{-1}\right)$ and white circles denote sites with $\mathrm{O}_{2}>4.6 \mathrm{mg} \mathrm{L}^{-1}$. Gray and black lines illustrate boundaries of Water Framework Directive areas.

$100 \mathrm{~m}$ in AS, similarly to SA where narrow, deep valleys separate mosaics of islands and reefs. Substrate in both areas varies from organic-rich soft sediments in sheltered locations to hard clay, till and bedrock in exposed areas. At greater depths, soft sediments are common due to limited water movement. As a whole, the study area with rich topographic heterogeneity forms one of the most diverse seabed areas in the world (Kaskela et al., 2012). In many areas hypoxia is a result of strong water stratification, slow water exchange and complex seabed topography, creating pockets of stagnant water (Conley et al., 2011; Valanko et al., 2015; Jokinen et al., 2018). Thus, the area is ideal for testing hypotheses of topographical controls for hypoxia formation.

\subsection{Hypoxia data}

Bottom-water hypoxia is the main factor structuring benthic communities in the Baltic Sea (Villnas et al., 2012; Norkko et al., 2015). A total of $2 \mathrm{mg} \mathrm{L}^{-1}$ of $\mathrm{O}_{2}$ is usually considered a threshold where coastal organisms start to show symp- toms of the lack of oxygen, and this limit has been commonly used in various global reviews (Diaz and Rosenberg, 1995b, 2008). Some studies have however concluded that $2 \mathrm{~m} \mathrm{~L}^{-1}$ is below the empirical sublethal and lethal oxygen limit for many species (Vaquer-Sunyer and Duarte, 2008; Conley et al., 2009). Here we define hypoxia based on two ecologically meaningful limits: moderately hypoxic $<4.6 \mathrm{mg} \mathrm{L}^{-1}$ $\mathrm{O}_{2}$ - as this has been estimated to be a minimum safe limit for species survival, behavior and functioning in benthic communities (Norkko et al., 2015) - and severely hypoxic $<2 \mathrm{mg} \mathrm{L}^{-1} \mathrm{O}_{2}$, which describes zones where larger marine organisms suffer from severe mortality (Vaquer-Sunyer and Duarte, 2008). As no reference values exist for severity of hypoxia to marine organisms based on the frequency of hypoxic events (Norkko et al., 2012, 2015; Villnas et al., 2012), we here define a site to be prone to hypoxic events, i.e., occasionally hypoxic, if it experienced hypoxia $\left(\mathrm{O}_{2}<2\right.$ and $<4.6 \mathrm{mg} \mathrm{L}^{-1}$ ) at least once during the study period. If hypoxia was recorded in $\geq 20 \%$ of the visits, it was categorized as frequently hypoxic. We consider this to be ecologically relevant, as species develop symptoms already from short exposures to hypoxia (Villnas et al., 2012; Norkko et al., 2015). This is also justified, as our oxygen data are from $\sim 1 \mathrm{~m}$ above the seafloor, suggesting that the actual oxygen concentrations at sediment where benthic species live are probably lower.

Data from oxygen profiles were collated from the national monitoring environmental data portals Hertta (https://www.syke.fi/en-US/Open_information/ Open_web_services/Environmental_data_API, last access: 30 January 2019) and SHARK (https: //www.smhi.se/data/oceanografi/havsmiljodata, last access: 15 January 2019). Data were available from 808 monitoring sites. Only the months of August and September 2000-2016 were considered, as hypoxia is usually a seasonal phenomenon occurring in late summer when water temperatures are warmest (Conley et al., 2011).

\subsection{Predictors}

For modeling hypoxia occurrences, we developed five geomorphological metrics: (1) bathymetric position indices (BPIs) with varying search radii, (2) depth-attenuated wave exposure (SWM(d)), (3) topographic shelter index (TSI), (4) arc-chord rugosity (ACR) and (5) vector ruggedness measure (VRM). BPI is a marine modification of the terrestrial version of the topographic position index (TPI), originally developed for terrestrial watersheds (Weiss, 2001). BPI is a measure of a bathymetric surface higher (positive values) or lower (negative values) than the overall seascape. BPI values close to zero are either flat areas or areas with constant slope. Here, BPIs represent topographical depressions and crests at scales of $0.1,0.3,0.5,0.8$ and $2 \mathrm{~km}$ calculated with Benthic Terrain Modeler (v3.0) (Walbridge et al., 2018). SWM(d) estimates dominant wave frequency at a given location with 
the decay of wave exposure with depth and takes into account the diffraction and refraction of waves around islands (Bekkby et al., 2008). SWM(d) characterizes areas where water movement is slower, i.e., where water resides longer. In terrestrial realms, landform influences on windthrow patterns, i.e., exposure to winds, have been noted in several studies, e.g., Kramer (2001) and Ashcroft et al (2008). Here, we introduce an analogous version of windthrow-prone areas to the marine realm, i.e., a wave-prone metric: topographic shelter index (TSI), which differentiates wave directions and takes into account the sheltering effects of islands (i.e., exposure above sea level). The identification of wave-prone areas was calculated for the azimuths multiple of 15 (0$345^{\circ}$ ) and for altitudes (corresponding to the angle of light source) ranging from 0.125 to $81^{\circ}$. For each altitude the produced wave-prone areas were combined to an index value for each grid cell. Surface roughness is a commonly used measure of topographical complexity in terrestrial studies and has been used in marine realms as well (see, e.g., Dunn and Halpin, 2009, for modeling habitats of hard substrates and Walker et al., 2009, for complexity of coral reef habitats). Here, we consider two approaches for estimating seascape rugosity: arc-chord rugosity (ACR) and vector ruggedness measure (VRM). ACR is a landscape metrics, which evaluates surface ruggedness using a ratio of contoured area (surface area) to the area of a plane of best fit, which is a function of the boundary data (Du Preez, 2015). VRM, on the other hand, is a more conservative measure of surface roughness developed for wildlife habitat models and is calculated using a moving $3 \times 3$ window where a unit vector orthogonal to the cell is decomposed using the three-dimensional location of the cell center, the local slope and aspect. A resultant vector is divided by the number of cells in the moving window (Sappington et al., 2007). Both rugosity indices were used here to identify areas with complex marine geomorphology. Differences of predictor variables are illustrated in Fig. 2. We also included geographical study areas as predictors, in order to highlight the differences between WFD areas.

\subsection{Hypoxia models}

Based on the ecologically meaningful limits of hypoxia (see Sect. 2.2), we built four separate oxygen models based on frequency and severity of hypoxia: occasional with $\mathrm{O}_{2}$ limits $<4.6$ and $<2 \mathrm{mg} \mathrm{L}^{-1}$ (hereafter referred to as $\mathrm{OH}_{4.6}$ and $\mathrm{OH}_{2}$ ) and frequent hypoxia with $\mathrm{O}_{2}$ limits $<4.6$ and $<2 \mathrm{mg} \mathrm{L}^{-1}$ (hereafter referred to as $\mathrm{FH}_{4.6}$ and $\mathrm{FH}_{2}$ ). We used the generalized boosted regression model (GBM) and its extension boosted regression trees (BRTs), a method from statistical and machine learning traditions (De'ath and Fabricius, 2000; Hastie et al., 2001; Schapire, 2003). BRT optimizes predictive performance through integrated stochastic gradient boosting (Natekin and Knoll, 2013) and forms the best model for prediction based on several models.
Ideal model tuning parameters (learning rate, bag fraction, tree complexity) for our hypoxia models were based on optimizing the model performance, i.e., minimizing the prediction error. The learning rate was set to 0.001 to determine the contribution of each successive tree to the final model. We varied the number of decision rules controlling model interaction levels, i.e., tree complexities, between 3 and 6 . We shuffled the hypoxia data randomly into 10 subsets for training $(70 \%)$ and testing $(30 \%)$ while preserving the prevalence ratio of hypoxia occurrence. Hypoxia models were developed based on 10-fold cross-validation, and the resulting final, best models leading to the smallest predictive errors were chosen to predict the probability of detecting hypoxia across the study region at a resolution of $20 \mathrm{~m}$. We believe such a high resolution is necessary due to the complexity of the archipelagoes of Finland and Sweden. Model predictions for the whole seascape were repeated 10 times with different model fits from data subsets (40 separate model predictions) to identify areas where models agree on the area to be potentially hypoxic. Model performances were estimated against the independent data (test data $30 \%$ ), not used in model fitting in order to evaluate the potential overfitting of the models. Analyses were performed in R 3.5.0 (R Core Team, 2018) with $R$ libraries gbm (Greenwell et al., 2018), PresenceAbsence (Freeman and Moisen, 2008) and relevant functions from Elith et al. (2008).

Variable selection in BRT is internal by including only relevant predictors when building models. The importance of predictors is based on the time each predictor is chosen in each split, averaged over all trees. Higher scores (summed up to $100 \%$ ) indicate that a predictor has a strong influence on the response (Elith et al., 2008). Although BRT is not sensitive to collinearity of predictors, the ability to identify the strongest predictors by decreasing the estimated importance score of highly correlated ones is detrimental to the interpretability of models (Gregorutti et al., 2017). Selecting only an optimal and a minimal set of variables for modeling, i.e., finding all relevant predictors and keeping the number of predictors as small as possible, reduces the risk of overfitting and improves the model accuracy. Here, most of the predictors describe the seascape structure and are somehow related to the topography of the seabed. We estimated the potential to drop redundant predictors, i.e., those that would lead to marked improvement in model performance if left out from the model building. For this, we used internal backward feature selection in BRT. However, we did not find marked differences in predictive performances and used all predictors.

Estimation of model fits and predictive performances was based on the ability to discriminate a hypoxic site from an oxic one, evaluated with the area under the curve (AUC) (Jiménez-Valverde and Lobo, 2007) and simply with the percent correctly classified (PCC) (Freeman and Moisen, 2008). AUC is a measure of the detection accuracy of true positives (sensitivity) and true negatives (specificity), and AUC values 

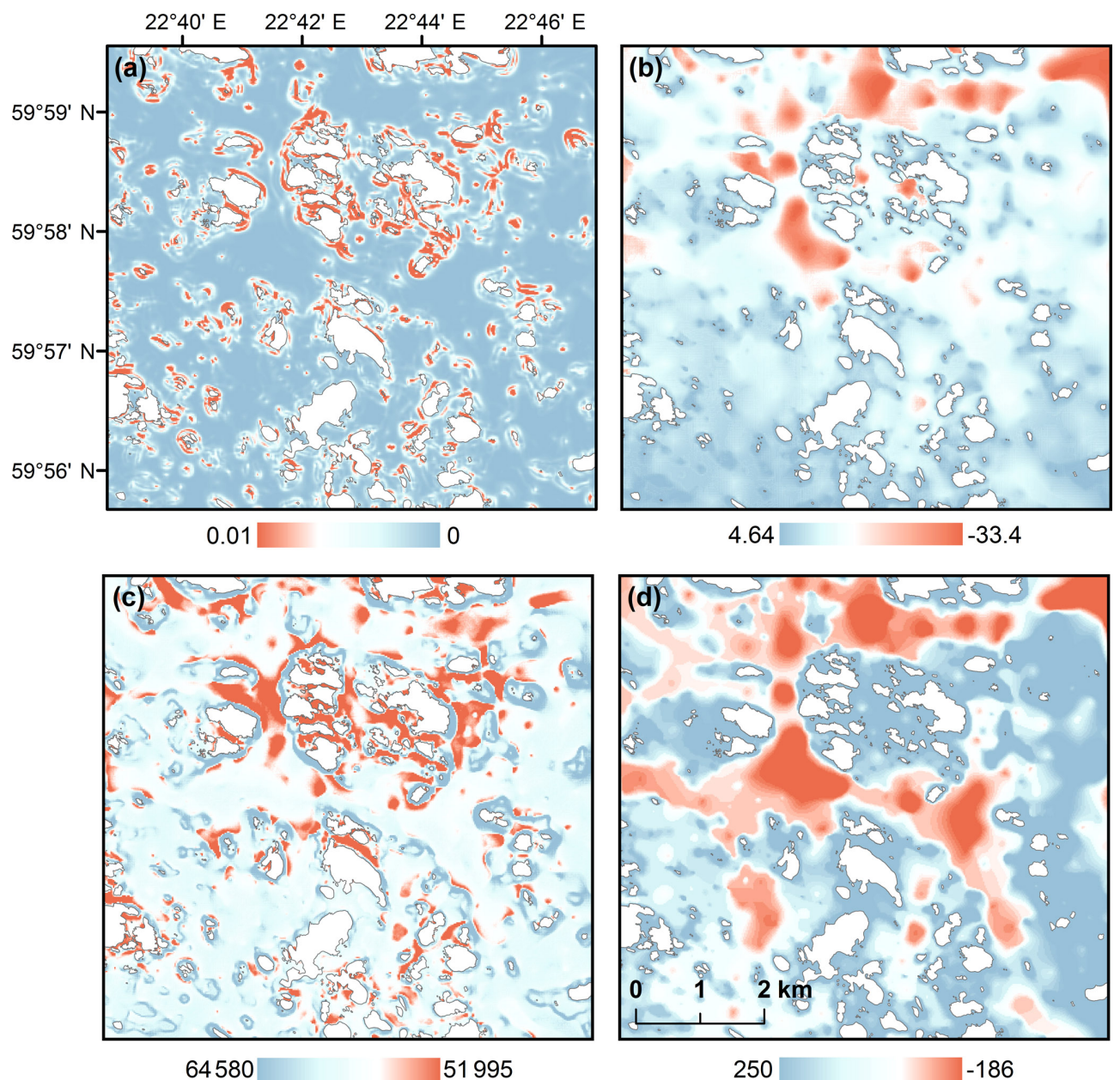

Figure 2. Predictor variables developed for hypoxia ensemble models: (a) vector ruggedness measure (VRM), (b) depth-attenuated wave exposure (SWM(d)), (c) topographic shelter index (TSI) and (d) bathymetric position index (BPI) with a search radius of $2 \mathrm{~km}$. Red color represents rugged seafloors (VRM), sheltered areas (SWM(d), TSI) and depressions (BPI2). Islands are shown as white.

above 0.9 indicate excellent, of $0.7-0.9$ indicate good and below 0.7 indicate poor predictions.

We transformed hypoxia probability predictions into binary classes of presence/absence and estimated the relative area of potentially hypoxic waters due to topographical reasons. Although dichotomization of probability predictions flattens the information content, it facilitates the interpretation of results and is needed for management purposes. The predicted range of hypoxia and the potential geographical extent enables the identification of problematic areas and facilitates management actions in a cost-effective way. There are various approaches for determining thresholds, which are based on the confusion matrix, i.e., how well the model captures true/false presences or true/false absences. Usually the threshold is defined to maximize the agreement between observed and predicted distributions. Widely used thresholds, such as 0.5 , can be arbitrary unless the threshold equals prevalence of presences in the data, i.e., the frequency of occurrences (how many presences of the total dataset) (Liu et al., 2005). Here, we define thresholds objectively based on an agreement between predicted and observed hypoxia prevalence. This approach underestimates areas potentially hypoxic (see Sect. 3.4) and is expressed here as a conservative estimate.

\section{Results}

\subsection{Hypoxia in complex coastal archipelagos}

During 2000-2016 hypoxia was rather common throughout the whole study region. In Finland, hypoxia mostly occurred on the southern coast, as in the Archipelago Sea (AS), eastern Gulf of Finland (EGoF) and western Gulf of Finland (WGoF) hypoxic events were recorded frequently. Only $\sim 30 \%$ of coastal monitoring sites in AS, EGoF and SA were not hypoxic; i.e., oxygen concentrations were always above $4.6 \mathrm{mg} \mathrm{L}^{-1}$ (see percentages in brackets in Fig. 3). Coastal areas in the Stockholm archipelago (SA) were also regularly 
hypoxic, with $70 \%$ of the sites moderately $\left(\mathrm{O}_{2}<4.6 \mathrm{mg} \mathrm{L}^{-1}\right)$ and $53 \%$ severely $\left(\mathrm{O}_{2}<2 \mathrm{mg} \mathrm{L}^{-1}\right)$ hypoxic. Severe hypoxia was quite a localized phenomenon in Finland, as it was recorded at ca. $30 \%$ of sites in AS and EGoF. However, in WGoF there are sites where severe hypoxia is rather persistent, as every sampling event was recorded as hypoxic. The same applies to SA, as there are quite a few sites repeatedly severely hypoxic. In contrast, in the northern study area, Gulf of Bothnia (GoB), hypoxic events occurred rather infrequently, as in $98 \%$ of sites $\mathrm{O}_{2}$ was above $2 \mathrm{mg} \mathrm{L}^{-1}$ and in $87 \% \mathrm{O}_{2}$ was above $4.6 \mathrm{mg} \mathrm{L}^{-1}$ (Fig. 3).

\subsection{Importance of predictors}

Models developed on 566 sites, based on 10-fold crossvalidation and 10 repeated predictions; the most influential predictor (averaged across models) was $\operatorname{SWM}(\mathrm{d})$, with a mean contribution of $33 \%( \pm 5 \%)$ (Fig. 4). The contribution of $\mathrm{SWM}(\mathrm{d})$ was highest for frequent, severe hypoxia $\left(\mathrm{FH}_{2}\right)(41 \pm 3 \%)$, whereas for occasional, moderate hypoxia $\left(\mathrm{OH}_{4.6}\right)$ the influence was markedly lower $(25 \pm 5 \%)$. This supports the hypothesis that in sheltered areas, where water movement is limited, severe oxygen deficiency is likely to develop. It is also noteworthy that depth was not the most important driver of hypoxia in coastal areas. This suggests that coastal hypoxia is not directly dependent on depth but that depressions that are especially steep and isolated are more sheltered and become more easily hypoxic than smoother depressions.

Across models, BPIs identifying wider sinks (BPI2 and BPI0.8) were more influential than BPIs identifying smaller sinks (BPIs 0.1, 0.3 and 0.5), and terrain ruggedness measures, VRM and ACR, were more important for frequent severe hypoxia $\left(\mathrm{FH}_{2}\right)$ than for moderate hypoxia $\left(\mathrm{FH}_{4.6}\right)$. The relatively high contribution of topographic shelter (TSI $7 \pm 2 \%$ ) indicates that, in areas where there are higher islands, the basins between are prone to hypoxia formation.

\subsection{Model performance}

Predictive ability of models to detect sites as hypoxic across models was good, with a mean 10 -fold cross-validated AUC of $0.85( \pm 0.02)$ and mean AUC of $0.86( \pm 0.03)$ when evaluated against independent test data for 242 sites (30\% of sites) (Fig. 5a). Models classified on average $88 \%$ of sites correctly $\left(\mathrm{PCC}_{\mathrm{cv}}\right.$ in Fig. 5b) and performed only slightly worse when evaluated against independent data, with $81 \%( \pm 3 \%)$ correctly classified $\left(\mathrm{PCC}_{\mathrm{in}}\right.$ in Fig. 5b). Models developed for frequent hypoxia $\left(\mathrm{FH}_{2}\right.$ and $\mathrm{FH}_{4}$.6) were better (mean $\mathrm{AUC}_{\mathrm{in}}$ $0.88 \pm 0.03$ ) compared to occasional hypoxia models (mean $\left.\mathrm{AUC}_{\text {in }} 0.84 \pm 0.04\right)$. This suggests that other factors beyond topographical proxies contribute relatively more to the occurrence of occasional hypoxia than for frequent hypoxia.

\subsection{Hypoxic areas}

Although hypoxia was commonly recorded in all WFD areas, except in the Gulf of Bothnia, the potential geographical extent of hypoxic seafloors shows a rather different pattern. Based on models, topographically prone areas represent only a small part of the coastal areas, with less than $25 \%$ affected (Fig. 6). Frequent, severe hypoxia $\left(\mathrm{O}_{2}<2 \mathrm{mg} \mathrm{L}^{-1}\right)$ was most prominent in the Archipelago Sea and Stockholm archipelago, although representing only a small fraction of the total areas (on average $1.5 \%$ and $3.7 \%$, respectively). Problematic areas based on the models are the Archipelago Sea, Stockholm archipelago and western Gulf of Finland. Those areas seem to be topographically prone to oxygen deficiency. Moreover, around $10 \%$ of areas in the eastern Gulf of Finland are vulnerable to occasional moderate hypoxia but less to severe hypoxia. Areas predicted as hypoxic in the Gulf of Bothnia were less than $<2 \%$, which supports our hypothesis of the facilitating role that topography potential has. There are fewer depressions (Supplement Fig. S1), and the seafloor is topographically less complex than in the other study areas.

\section{Discussion}

Hypoxia has been increasing steadily since the 1960s, and anoxic areas are seizing the seafloor, suffocating marine organisms in the way (Diaz and Rosenberg, 2008; Breitburg et al., 2018). Understanding the factors affecting the severity and spatial extent of hypoxia is essential in order to estimate rates of deoxygenation and its consequences to the marine ecosystems (Breitburg et al., 2018). Earlier studies have reported coastal hypoxia to be a global phenomenon (Diaz and Rosenberg, 2008; Conley et al., 2011) and is known to be widespread in the Baltic Sea (Conley et al., 2011). Our results confirmed this and showed that coastal hypoxia is perhaps a more common phenomenon than previously anticipated. According to our results, over $50 \%$ of sites in the complex archipelagoes of Finland and Sweden experienced hypoxia that is ecologically significant $\left(\mathrm{O}_{2}<4.6 \mathrm{mg} \mathrm{L}^{-1}\right)$. Especially alarming was the intensity of it. For instance, the Stockholm archipelago suffered frequently from severe hypoxia $\left(\mathrm{O}_{2}<2 \mathrm{mg} \mathrm{L}^{-1}\right)$, as approximately half of the coastal monitoring sites were hypoxic across our study period (Fig. 3). This demonstrates that deoxygenated seafloors are probably even more common in coastal environments than previously reported (Karlsson et al., 2010; Conley et al., 2011). It is notable that in areas above the permanent halocline, hypoxia is in many areas seasonal and develops after the building of thermocline in late summer (Conley et al., 2011). It is therefore probable that many of the areas we recognized as hypoxic may well be oxygenated during winter and spring. This does not however reduce the severity of the phenomenon. Even a hypoxic event of short duration, e.g., a few days, will reduce ecosystem resistance 

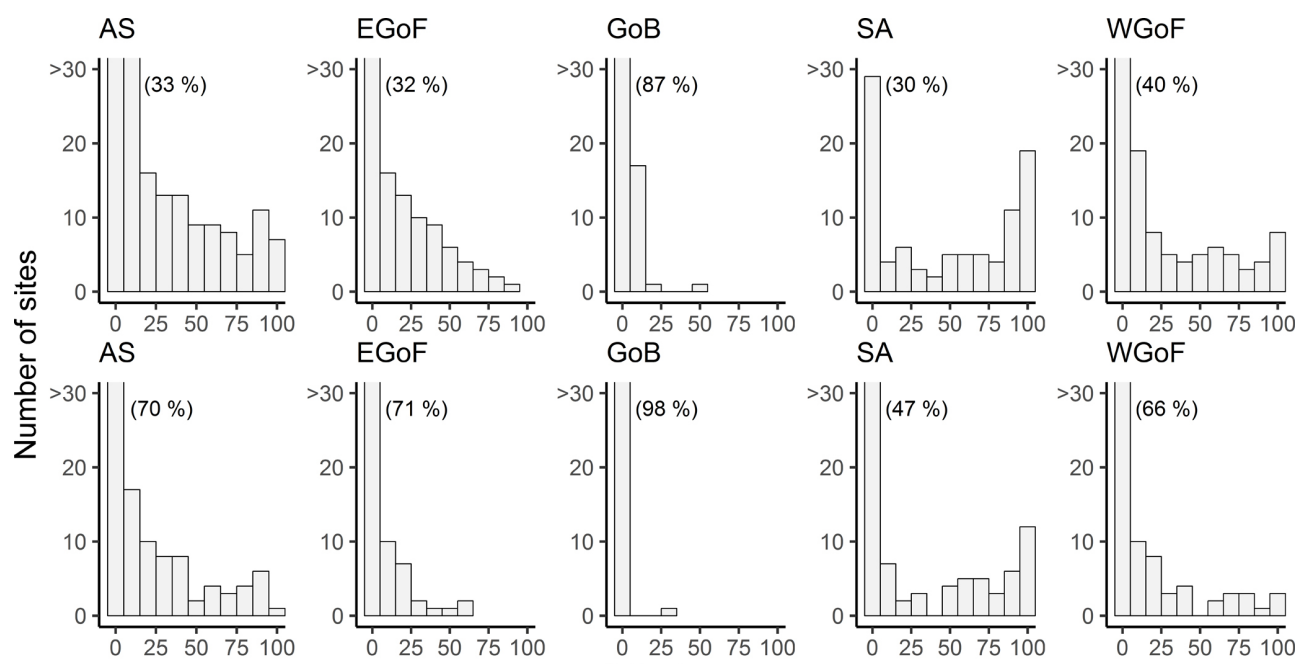

Frequency (\%) of hypoxic events
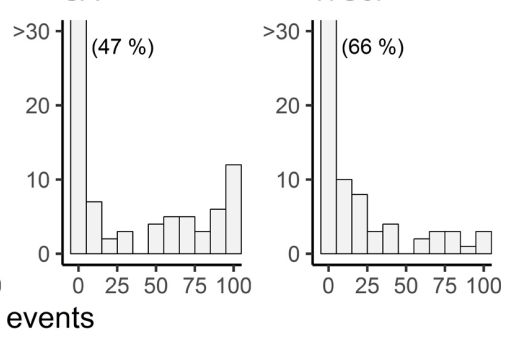

Figure 3. Frequencies of hypoxic events at coastal monitoring sites across Water Framework Directive areas: Archipelago Sea (AS), eastern Gulf of Finland (EGoF), Gulf of Bothnia (GoB), Stockholm archipelago (SA) and western Gulf of Finland (WGoF). Upper panels indicate $\mathrm{O}_{2}<4.6 \mathrm{mg} \mathrm{L}^{-1}$ and lower panels $\mathrm{O}_{2}<2 \mathrm{mgL}^{-1}$. Numbers in brackets indicate the percentage of sites with $\mathrm{O}_{2}>4.6$ (upper panel) and $\mathrm{O}_{2}>2 \mathrm{mg} \mathrm{L}^{-1}$ (lower panel). Number of sites over 30 are not shown.

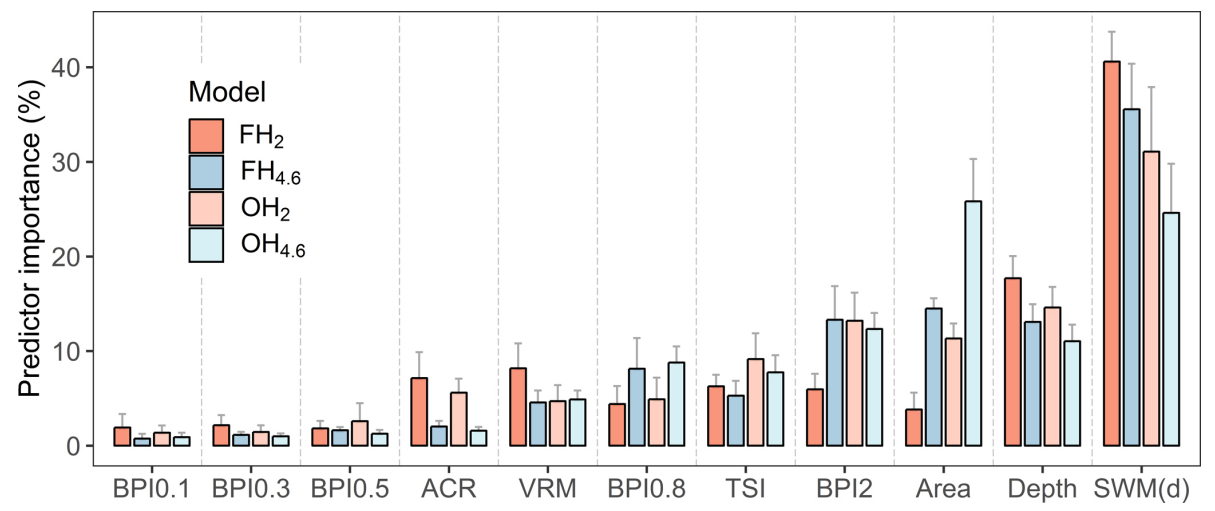

Figure 4. Importance of predictors based on 10 prediction rounds. Predictors are color-coded based on models. $\mathrm{FH}_{2}$ : frequent, severe hypoxia $\left(\mathrm{O}_{2}<2 \mathrm{mgL}^{-1}\right) ; \mathrm{FH}_{4.6}$ : frequent, moderate hypoxia $\left(\mathrm{O}_{2}<4.6 \mathrm{mg} \mathrm{L}^{-1}\right) ; \mathrm{OH}_{2}$ : occasional, severe hypoxia $\left(\mathrm{O}_{2}<2 \mathrm{mg} \mathrm{L}-1\right)$, and $\mathrm{OH}_{4.6}$ : occasional, moderate hypoxia $\left(\mathrm{O}_{2}<4.6 \mathrm{mg} \mathrm{L}^{-1}\right)$. Whiskers represent standard deviations.

to further hypoxic perturbation and affect the overall ecosystem functioning (Villnas et al., 2013).

As our study suggests, topographically prone areas to deoxygenation represent less than $25 \%$ of seascapes. However, most of the underwater nature values in the Finnish sea areas are concentrated on relatively shallow areas where there exist enough light and suitable substrates (Virtanen et al., 2018; Lappalainen et al., 2019). Shallow areas also suffer from eutrophication and rising temperatures due to changing climate and are most probably the ones that are particularly susceptible to hypoxia in the future (Breitburg et al., 2018). This suggests that seasonal hypoxia may become a recurrent phenomenon in shallow areas above the thermocline in late summer.
Although extensive 3-D models have been developed for the main basins of the Baltic Sea (Meier et al., 2011b, 2012a, 2014) the previous reports on the occurrence of coastal hypoxia have mostly been based on point observations (Conley et al., 2009, 2011). Due to the lack of data, and computational limitations, no biogeochemical model has (yet) encompassed the complex Baltic Sea archipelago with a resolution needed for adjusting local management decisions. This study provides a novel methodology to predict and identify areas prone to coastal hypoxia without data on currents, stratification or biological variables, and without complex biogeochemical models. Our approach is applicable to other low-energy and nontidal systems, such as large shallow bays and semienclosed or enclosed sea areas. The benefit of this approach is that it requires far less computational power than a fine-scale 
(a)

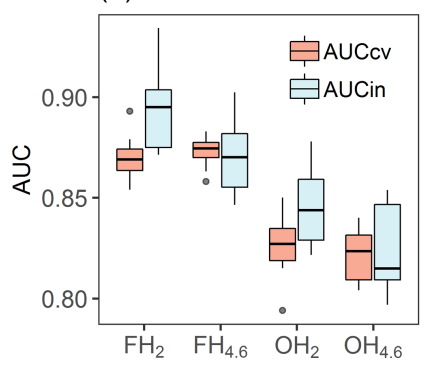

(b)

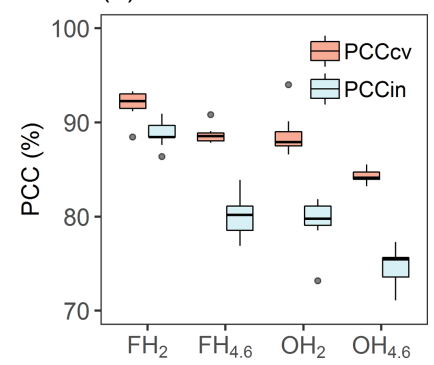

Figure 5. Model performances based on (a) area under the curve values with 10 -fold cross-validation $\left(\mathrm{AUC}_{\mathrm{cv}}\right)$ and against independent test data (30\% of sites) $\left(\mathrm{AUC}_{\mathrm{in}}\right)$ as well as (b) percent of correctly classified with 10 -fold cross-validation $\left(\mathrm{PCC}_{\mathrm{cv}}\right)$ and against independent data $\left(\mathrm{PCC}_{\mathrm{in}}\right)$.

(a) $\mathrm{FH}_{2}$

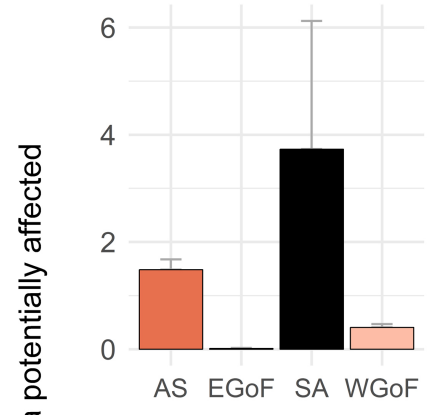

(c) $\mathrm{OH}_{2}$

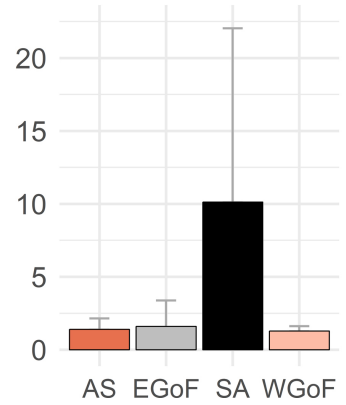

(b) $\mathrm{FH}_{4.6}$

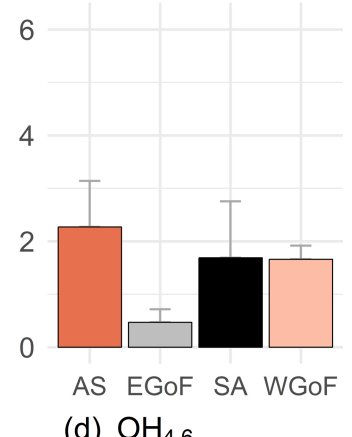

(d) $\mathrm{OH}_{4.6}$

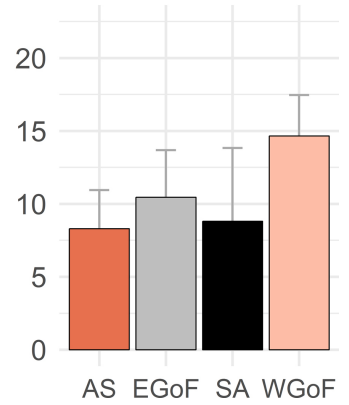

Figure 6. Percent (\%) of areas potentially affected by hypoxia with varying frequencies (occasional and frequent) and hypoxia severities $\left(\mathrm{O}_{2}<4.6\right.$ and $\left.\mathrm{O}_{2}<2 \mathrm{mg} \mathrm{L}^{-1}\right)$. AS: Archipelago Sea; EGoF: eastern Gulf of Finland; SA: Stockholm archipelago; and WGoF: western Gulf of Finland. GoB is not reported as areas potentially affected were below $2 \%$ across all models.

3-D numerical modeling. By using relatively simple proxies describing depressions of stagnant water, we were able to create detailed hypoxia maps for the entire Finnish coastal area $\left(23500 \mathrm{~km}^{2}\right)$ and Stockholm archipelago $\left(5100 \mathrm{~km}^{2}\right)$, thus enabling a quick view of potentially hypoxic waters (Fig. 7).

We quantified the facilitating role of seafloor complexity for the formation of hypoxia. Sheltered, topographically het-

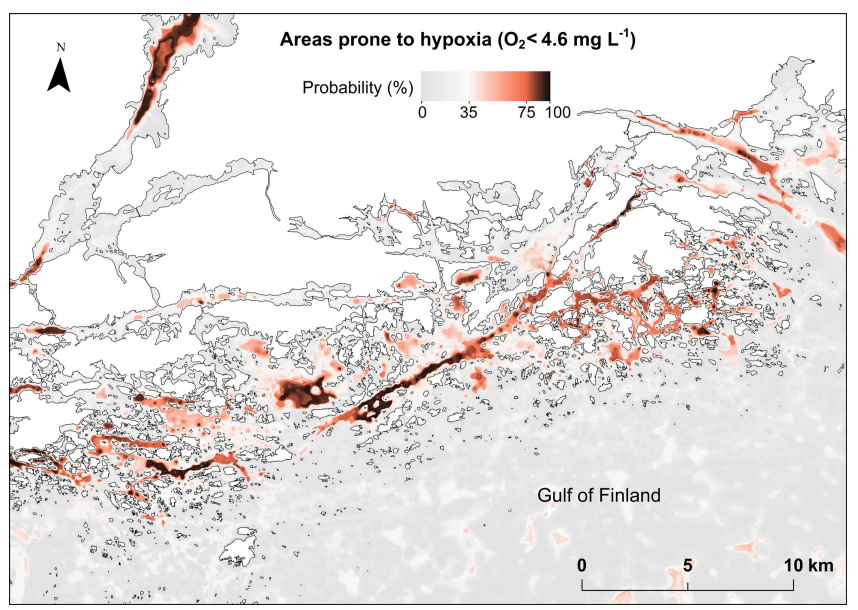

Figure 7. Modeled probability (\%) of detecting frequent hypoxia $\mathrm{O}_{2}\left(<4.6 \mathrm{mg} \mathrm{L}^{-1}\right)$ due to topography in an example area off the southern coast of Finland. Land shown as white color.

erogeneous areas, where water exchange is limited, are more susceptible to developing hypoxia according to our results. This statement is quite intuitive, but it has not previously been quantified. It is also noteworthy that coastal hypoxia is not only related to depth; deep seafloors are not automatically hypoxic or anoxic. In our study, hypoxia was common in shallow and moderate depths of $10-45 \mathrm{~m}$. For instance, in the Archipelago Sea, deep (60-100 m) channels are not usually hypoxic, as strong currents tend to keep them oxygenated throughout the year (Virtasalo et al., 2005). Shallow areas can be restricted by slow water movement due to topographical reasons, thus creating opportunities for hypoxia formation.

We emphasize that our models only indicate where hypoxia may occur simply due to restricted water exchange. Any deviations from this pattern are probably caused by either hydrographic factors, which the hypoxia model based on topography did not account for (such as strong currents in elongated, wide channels), or biogeochemical factors. Especially high external loading, and local biogeochemical and biological processes (nutrient cycling between sediment and the water), obviously modifies the patterns and severity of hypoxia also in the coastal areas. Oxygen deficiency has been projected to increase faster in the coastal systems than in the open sea (Gilbert et al., 2010; Altieri and Gedan, 2015). Such coastal areas are usually affected by external nutrient loading from the watershed. In larger basins and sea areas dominated by large river systems, such as the central Baltic Sea, Gulf of Mexico and Chesapeake Bay, large-scale oceanographic and biogeochemical processes, or external loading, govern the depth and extent of hypoxia. This is the case also in the Baltic Sea. In areas where our models underestimate oxygen deficiency, major nutrient sources, e.g., rivers, cities or intensive agricultural areas, probably contribute to hypoxia formation. However, in extremely complex archipelago areas, 
such as the Finnish and Swedish archipelago, physical factors limiting lateral and vertical movement of water probably facilitate, and in some areas even dictate, the development of hypoxia.

There were spatial differences in the frequency and severity of hypoxia that can be explained by topographical characteristics of the areas, external loading and interaction with the adjacent deeper basins. For instance, in the Stockholm archipelago severe hypoxia covered the largest percentage of seascapes of all study areas. The Stockholm archipelago is part of a joint valley landscape with deep, steep areas also in the inner parts where wave forcing is exceptionally low and disconnected from the open sea, making it very susceptible to hypoxia, which was also confirmed by the model. In Finland, the inner archipelago is mostly shallow, with steep but wider channels occurring only in the Archipelago Sea. These elongated channels are connected to adjacent open-sea areas and thus well-ventilated, as opposed to the narrow channels of the Stockholm archipelago. Geographically, hypoxia in Finland was most prominent in the Archipelago Sea and the Gulf of Finland, where the inner archipelago is isolated from the open sea, and the complex topography results in overall poor water exchange in the existing depressions. Both the Stockholm archipelago and the Archipelago Sea suffer from external loading from the associated watersheds and internal loading from sediments, which probably contributes to the poor oxygen status of these areas (Puttonen et al., 2014; Walve et al., 2018). Biogeochemical factors were however not accounted for by our analysis and cannot be used in explaining the observed spatial differences.

In the Gulf of Finland, eutrophication increases in the open sea from west to east, which has traditionally been explained by nutrient discharges from the Neva River (HELCOM, 2018). In our data there was however no clear gradient of coastal hypoxia increasing towards east. In contrast, frequent hypoxia was more common in the Archipelago Sea and western Gulf of Finland than in the eastern Gulf of Finland, where hypoxia occurred only occasionally. This suggests that the coastal hypoxia is more dependent on local processes, i.e., internal loading and external loading from nearby areas, whereas open-sea hypoxia is governed by basin-scale dynamics. However, the occasional nature of hypoxia in the eastern Gulf of Finland may be at least partly caused by the dependency on the deep waters of the open parts of the Gulf of Finland. The Gulf of Finland is an embayment, $400 \mathrm{~km}$ long and 50-120 km wide, which has an open western boundary to the Baltic Proper. A tongue of anoxic water usually extends from the central Baltic Sea into the Gulf of Finland along its deepest parts. Basin-scale oceanographic and atmospheric processes influence how far east this tongue proceeds into the Gulf of Finland each year (Alenius et al., 2016). It is possible that, when this anoxic tongue extends close to eastern Gulf of Finland, it also worsens the oxygen situation of the EGoF archipelago.
In the Gulf of Bothnia, hypoxia was markedly less frequent and severe than in the other study areas. GoB has a relatively open coastline with only few depressions (see Fig. S1) and strong wave forcing, which probably enhances the mixing of water in the coastal areas. Moreover, as the open-sea areas of the Gulf of Bothnia are well oxygenated due to a lack of halocline and topographical isolation of GoB from the Baltic Proper (by the sill between these basins) (Leppäranta and Myrberg, 2009), hypoxic water is not advected from the open sea to the coastal areas.

Such observations suggest that formation of coastal hypoxia is not totally independent from basin-scale oxygen dynamics. While we suggest that coastal hypoxia can be formed entirely based on local morphology and local biogeochemical processes, the relatively low occurrence of hypoxia in the Gulf of Bothnia and differences in frequency of hypoxia in different parts of the Gulf of Finland both highlight the interaction of these coastal areas with the Baltic Proper.

While our results confirm that hypoxia in most study areas is a frequently occurring phenomenon, they also show that areas affected by hypoxia are geographically still limited. Our modeling results indicate that, overall, less than $25 \%$ of the studied sea areas were afflicted by some form of hypoxia (be it recurrent or occasional), and less than $6 \%$ of seascapes were plagued by frequent, severe hypoxia. The relatively small spatial extent of coastal hypoxia does not mean that it is not a harmful phenomenon. In the Stockholm archipelago, severe hypoxia is a pervasive and persistent phenomenon, and also in Finland, many local depressions are often hypoxic. Anoxic local depressions probably act as local nutrient sources, releasing especially phosphorus to the water column, which further enhances pelagic primary production. Such a vicious circle tends to worsen the eutrophication and maintain the environment in a poor state (Pitkänen et al., 2001; Vahtera et al., 2007). In this way, even smallsized anoxic depressions, especially if they are many, may affect the ecological status of the whole coastal area. Moreover, as climate change has been projected to increase water temperatures and worsen hypoxia in the Baltic Sea (Meier et al., 2011a), shallow archipelago areas that typically have high productivity, warm up quickly and are topographically prone to hypoxia may be especially vulnerable to the negative effects of climate change.

In order to establish reference conditions and implement necessary and cost-efficient measures to reach the goals of international agreements such as the EU Water Framework Directive (WFD, 2000/60/EC), the Marine Strategy Framework Directive (MSFD, 2008/56/EC) and the HELCOM Baltic Sea Action Plan (BSAP), in-depth knowledge of ecological functions and processes as well as natural preconditions is needed. Although eutrophication is a problem for the whole Baltic Sea, nutrient abatement measures are taken locally. We therefore need to know where the environmental benefits are maximized and where natural conditions are likely to counteract any measures taken. As some places are natu- 
rally prone to hypoxia, our model could aid directing measures to places where they are most likely to be efficient, as well as explain why in some areas implemented measures do not have the desired effect. Our approach could be used to develop an early-warning system for identification of areas prone to oxygen loss and to indicate where eutrophication mitigation actions are most urgently needed.

\section{Conclusions}

While biogeochemical 3-D models have been able to accurately project basin-scale oxygen dynamics, describing spatial variation of hypoxia in coastal areas has remained a challenge. Recognizing that the enclosed nature of seafloors contributes to hypoxia formation, we used simple topographical parameters to model the occurrence of hypoxia in the complex Finnish and Swedish archipelagoes. We found that a surprisingly large fraction $(\sim 80 \%)$ of hypoxia occurrences could be explained by topographical parameters alone. Modeling results also suggested that less than $25 \%$ of the studied seascapes were prone to hypoxia during late summer. Large variation existed in the spatial and temporal patterns of hypoxia, however, with certain areas being prone to occasional severe hypoxia $\left(\mathrm{O}_{2}<2 \mathrm{mg} \mathrm{L}^{-1}\right)$, while others were more susceptible to recurrent moderate hypoxia $\left(\mathrm{O}_{2}<4.6 \mathrm{mg} \mathrm{L}^{-1}\right)$. Sheltered, topographically heterogeneous areas with limited water exchange were susceptible to developing hypoxia, in contrast to less sheltered areas with high wave forcing. In some areas oxygen conditions were either better or worse than predicted by the model. We assume that these deviations from the topographical background were caused by processes not accounted for by the model, such as hydrographical processes, e.g., strong currents causing improved mixing, or by high external or internal nutrient loading, inducing high local oxygen consumption. We conclude that formation of coastal hypoxia is probably primarily dictated by local processes, and can be quite accurately projected using simple topographical parameters, but that interaction with the associated watershed and the adjacent deeper basins of the Baltic Sea can also influence local oxygen dynamics in many areas. Our approach gives a practical baseline for various types of hypoxia-related studies and, consequently, decision-making. Identifying areas prone to hypoxia helps to focus research, management and conservation actions in a cost-effective way.

Data availability. Hypoxia point data and scripts for reproducing the models and plots are available at the Dryad data repository: https://doi.org/10.5061/dryad.cn5kh5m (Virtanen et al., 2019).

Supplement. The supplement related to this article is available online at: https://doi.org/10.5194/bg-16-3183-2019-supplement.
Author contributions. EAV and MV designed the study, EAV and ANS performed all analyses, EAV wrote the main text, and all authors contributed to the writing and editing of the manuscript.

Competing interests. The authors declare that they have no conflict of interest.

Acknowledgements. Elina A. Virtanen and Markku Viitasalo acknowledge the SmartSea project (grant nos. 292985 and 314225), funded by the Strategic Research Council of the Academy of Finland, and the Finnish Inventory Programme for the Underwater Marine Environment VELMU, funded by the Ministry of the Environment. Alf Norkko acknowledges the support of the Academy of Finland (no. 294853) and the Sophie von Julins Foundation. Antonia Nyström Sandman acknowledges the IMAGINE project (grant no. 15/247), funded by the Swedish EPA. We wish to thank two anonymous reviewers for insightful comments that significantly improved the manuscript.

Financial support. This research has been supported by the Strategic Research Council of the Academy of Finland (SmartSea project) (grant nos. 292985 and 314225), the Ministry of the Environment (the Finnish Inventory Programme for the Underwater Marine Environment VELMU), the Academy of Finland (grant no. 294853), and the Swedish EPA (IMAGINE project) (grant no. 15/247).

Review statement. This paper was edited by Carol Robinson and reviewed by two anonymous referees.

\section{References}

Alenius, P., Myrberg, K., Roiha, P., Lips, U., Tuomi, L., Pettersson, H., and Raateoja, M.: Gulf of Finland Physics, in: The Gulf of Finland assessment, edited by: Raateoja, M. and Setälä, O., Helsinki, Finnish Environment Institute, Reports of the Finnish Environment Institute, 27, 42-57, 2016.

Altieri, A. H. and Gedan, K. B.: Climate change and dead zones, Glob. Change Biol., 21, 1395-1406, https://doi.org/10.1111/gcb.12754, 2015.

Ashcroft, M. B., Chisholm, L. A., and French, K. O.: The effect of exposure on landscape scale soil surface temperatures and species distribution models, Landscape Ecol., 23, 211-225, https://doi.org/10.1007/s10980-007-9181-8, 2008.

Bekkby, T., Isachsen, P. E., Isaeus, M., and Bakkestuen, V.: GIS modeling of wave exposure at the seabed: A depthattenuated wave exposure model, Mar. Geod., 31, 117-127, https://doi.org/10.1080/01490410802053674, 2008.

Greenwell, B., Boehmke, B., Cunningham, J., and GBM Developers: gbm: Generalized Boosted Regression Models, R package version 2.1.4, available at: https:/CRAN.R-project.org/ package $=$ gbm (last access: 11 March 2019), 2018.

Breitburg, D., Levin, L. A., Oschlies, A., Grégoire, M., Chavez, F. P., Conley, D. J., Garçon, V., Gilbert, D., Gutiérrez, D., Isensee, 
K., Jacinto, G. S., Limburg, K. E., Montes, I., Naqvi, S. W. A., Pitcher, G. C., Rabalais, N. N., Roman, M. R., Rose, K. A., Seibel, B. A., Telszewski, M., Yasuhara, M., and Zhang, J.: Declining oxygen in the global ocean and coastal waters, Science, 359, 1-11, https://doi.org/10.1126/science.aam7240, 2018.

Buzzelli, C. P., Luettich Jr, R. A., Powers, S. P., Peterson, C. H., McNinch, J. E., Pinckney, J. L., and Paerl, H. W.: Estimating the spatial extent of bottom-water hypoxia and habitat degradation in a shallow estuary, Mar. Ecol. Prog. Ser., 230, 103-112, 2002.

Caballero-Alfonso, A. M., Carstensen, J., and Conley, D. J.: Biogeochemical and environmental drivers of coastal hypoxia, J. Mar. Syst., 141, 190-199, https://doi.org/10.1016/j.jmarsys.2014.04.008, 2015.

Carstensen, J., Andersen, J. H., Gustafsson, B. G., and Conley, D. J.: Deoxygenation of the Baltic Sea during the last century, P. Natl. Acad. Sci. USA, 111, 5628-5633, https://doi.org/10.1073/pnas.1323156111, 2014.

Conley, D. J., Humborg, C., Rahm, L., Savchuk, O. P., and Wulff, F.: Hypoxia in the Baltic Sea and basin-scale changes in phosphorus biogeochemistry, Environ. Sci. Technol., 36, 5315-5320, https://doi.org/10.1021/es025763w, 2002.

Conley, D. J., Björck, S., Bonsdorff, E., Carstensen, J., Destouni, G., Gustafsson, B. G., Hietanen, S., Kortekaas, M., Kuosa, H., Markus Meier, H. E., Müller-Karulis, B., Nordberg, K., Norkko, A., Nürnberg, G., Pitkänen, H., Rabalais, N. N., Rosenberg, R., Savchuk, O. P., Slomp, C. P., Voss, M., Wulff, F., and Zillén, L.: Hypoxia-Related Processes in the Baltic Sea, Environ. Sci. Technol., 43, 3412-3420, https://doi.org/10.1021/es802762a, 2009.

Conley, D. J., Carstensen, J., Aigars, J., Axe, P., Bonsdorff, E., Eremina, T., Haahti, B. M., Humborg, C., Jonsson, P., Kotta, J., Lannegren, C., Larsson, U., Maximov, A., Medina, M. R., Lysiak-Pastuszak, E., Remeikaite-Nikiene, N., Walve, J., Wilhelms, S., and Zillen, L.: Hypoxia Is Increasing in the Coastal Zone of the Baltic Sea, Environ. Sci. Technol., 45, 6777-6783, https://doi.org/10.1021/es201212r, 2011.

De'ath, G. and Fabricius, K. E.: Classification and regression trees: A powerful yet simple technique for ecological data analysis, Ecology, 81, 3178-3192, https://doi.org/10.1890/00129658(2000)081[3178:CARTAP]2.0.CO;2, 2000.

Diaz, R. and Rosenberg, R.: Marine benthic hypoxia: A review of its ecological effects and the behavioural response of benthic macrofauna, Oceanogr. Mar. Biol., 33, 245-303, 1995a.

Diaz, R. J. and Rosenberg, R.: Marine benthic hypoxia: A review of its ecological effects and the behavioural responses of benthic macrofauna, in: Oceanography and Marine Biology - an Annual Review, Vol. 33, edited by: Ansell, A. D., Gibson, R. N., and Barnes, M., Oceanography and Marine Biology, U. C. L. Press Ltd, London, 245-303, 1995b.

Diaz, R. J. and Rosenberg, R.: Spreading dead zones and consequences for marine ecosystems, Science, 321, 926-929, https://doi.org/10.1126/science.1156401, 2008.

Dunn, D. C. and Halpin, P. N.: Rugosity-based regional modeling of hard-bottom habitat, Mar. Ecol. Prog. Ser., 377, 1-11, 2009.

Du Preez, C.: A new arc-chord ratio (ACR) rugosity index for quantifying three-dimensional landscape structural complexity, Landscape Ecol., 30, 181-192, https://doi.org/10.1007/s10980014-0118-8, 2015.

Eilola, K., Meier, H. E. M., and Almroth, E.: On the dynamics of oxygen, phosphorus and cyanobacteria in the
Baltic Sea; A model study, J. Mar. Syst., 75, 163-184, https://doi.org/10.1016/j.jmarsys.2008.08.009, 2009.

Eilola, K., Gustafsson, B. G., Kuznetsov, I., Meier, H. E. M., Neumann, T., and Savchuk, O. P.: Evaluation of biogeochemical cycles in an ensemble of three state-of-the-art numerical models of the Baltic Sea, J. Mar. Syst., 88, 267-284, https://doi.org/10.1016/j.jmarsys.2011.05.004, 2011.

Elith, J., Leathwick, J. R., and Hastie, T.: A working guide to boosted regression trees, J. Anim. Ecol., 77, 802-813, https://doi.org/10.1111/j.1365-2656.2008.01390.x, 2008.

Eriksson, S. P., Wennhage, H., Norkko, J., and Norkko, A.: Episodic disturbance events modify predator-prey interactions in soft sediments, Estuar. Coast. Shelf S., 64, 289-294, https://doi.org/10.1016/j.ecss.2005.02.022, 2005.

Fennel, K. and Testa, J. M.: Biogeochemical Controls on Coastal Hypoxia, Annu. Rev. Mar. Sci., 11, 105-130, https://doi.org/10.1146/annurev-marine-010318-095138, 2019.

Fennel, K., Hetland, R., Feng, Y., and DiMarco, S.: A coupled physical-biological model of the Northern Gulf of Mexico shelf: model description, validation and analysis of phytoplankton variability, Biogeosciences, 8, 1881-1899, https://doi.org/10.5194/bg-8-1881-2011, 2011.

Fennel, K., Laurent, A., Hetland, R., Justic, D., Ko, D. S., Lehrter, J., Murrell, M., Wang, L. X., Yu, L. Q., and Zhang, W. X.: Effects of model physics on hypoxia simulations for the northern Gulf of Mexico: A model intercomparison, J. Geophys. Res.-Ocean. 121, 5731-5750, https://doi.org/10.1002/2015jc011577, 2016.

Freeman, E. A. and Moisen, G.: PresenceAbsence: An R Package for Presence-Absence Model Analysis, J. Stat. Softw., 23, 1-31, 2008.

Frölicher, T. L., Joos, F., Plattner, G. K., Steinacher, M., and Doney, S. C.: Natural variability and anthropogenic trends in oceanic oxygen in a coupled carbon cycleclimate model ensemble, Global Biogeochem. Cy., 23, 1-15, https://doi.org/10.1029/2008GB003316, 2009.

Gammal, J., Norkko, J., Pilditch, C. A., and Norkko, A.: Coastal Hypoxia and the Importance of Benthic Macrofauna Communities for Ecosystem Functioning, Estuar. Coast., 40, 457-468, https://doi.org/10.1007/s12237-016-0152-7, 2017.

Gilbert, D., Rabalais, N. N., Díaz, R. J., and Zhang, J.: Evidence for greater oxygen decline rates in the coastal ocean than in the open ocean, Biogeosciences, 7, 2283-2296, https://doi.org/10.5194/bg-7-2283-2010, 2010.

Gray, J. S., Wu, R. S. S., and Or, Y. Y.: Effects of hypoxia and organic enrichment on the coastal marine environment, Mar. Ecol. Prog. Ser., 238, 249-279, https://doi.org/10.3354/meps238249, 2002.

Gregorutti, B., Michel, B., and Saint-Pierre, P.: Correlation and variable importance in random forests, Stat. Comput., 27, 659-678, https://doi.org/10.1007/s11222-016-9646-1, 2017.

Hastie, T., Tibshirani, R., and Friedman, J. H.: The Elements of Statistical Learning: Data Mining, Inference, and Prediction, Springer-Verlag, New York, 2001.

HELCOM: Sources and pathways of nutrients to the Baltic Sea, Baltic Sea Environment Proceedings No. 153, 1-48, 2018.

Hordoir, R., Axell, L., Höglund, A., Dieterich, C., Fransner, F., Gröger, M., Liu, Y., Pemberton, P., Schimanke, S., Andersson, H., Ljungemyr, P., Nygren, P., Falahat, S., Nord, A., Jönsson, A., Lake, I., Döös, K., Hieronymus, M., Dietze, H., Löptien, U., 
Kuznetsov, I., Westerlund, A., Tuomi, L., and Haapala, J.: NemoNordic 1.0: a NEMO-based ocean model for the Baltic and North seas - research and operational applications, Geosci. Model Dev., 12, 363-386, https://doi.org/10.5194/gmd-12-363-2019, 2019.

Jiménez-Valverde, A. and Lobo, J. M.: Threshold criteria for conversion of probability of species presence to either-or presence-absence, Acta Oecol., 31, 361-369, https://doi.org/10.1016/j.actao.2007.02.001, 2007.

Jokinen, S. A., Virtasalo, J. J., Jilbert, T., Kaiser, J., Dellwig, O., Arz, H. W., Hänninen, J., Arppe, L., Collander, M., and Saarinen, T.: A 1500-year multiproxy record of coastal hypoxia from the northern Baltic Sea indicates unprecedented deoxygenation over the 20th century, Biogeosciences, 15, 3975-4001, https://doi.org/10.5194/bg-15-3975-2018, 2018.

Karlson, K., Rosenberg, R., and Bonsdorff, E.: Temporal and spatial large-scale effects of eutrophication and oxygen deficiency on benthic fauna in Scandinavian and Baltic waters - A review, in: Oceanography and Marine Biology, Vol. 40, edited by: Gibson, R. N., Barnes, M., and Atkinson, R. J. A., Oceanography and Marine Biology, Taylor \& Francis Ltd, London, 427-489, 2002.

Karlsson, O. M., Jonsson, P. O., Lindgren, D., Malmaeus, J. M., and Stehn, A.: Indications of Recovery from Hypoxia in the Inner Stockholm Archipelago, Ambio, 39, 486-495, https://doi.org/10.1007/s13280-010-0079-3, 2010.

Kaskela, A. M., Kotilainen, A. T., Al-Hamdani, Z., Leth, J. O., and Reker, J.: Seabed geomorphic features in a glaciated shelf of the Baltic Sea, Estuar. Coast. Shelf S., 100, 150-161, https://doi.org/10.1016/j.ecss.2012.01.008, 2012.

Kemp, W. M., Testa, J. M., Conley, D. J., Gilbert, D., and Hagy, J. D.: Temporal responses of coastal hypoxia to nutrient loading and physical controls, Biogeosciences, 6, 2985-3008, https://doi.org/10.5194/bg-6-2985-2009, 2009.

Kramer, M. G., Hansen, A. J., Taper, M. L., and Kissinger, E. J.: Abiotic controls on long-term windthrow disturbance and temperate rain forest dynamics in Southeast Alaska, Ecology, 10, 2749-2768 2001.

Laine, A. O., Sandler, H., Andersin, A.-B., and Stigzelius, J.: Long-term changes of macrozoobenthos in the Eastern Gotland Basin and the Gulf of Finland (Baltic Sea) in relation to the hydrographical regime, J. Sea Res., 38, 135-159, https://doi.org/10.1016/S1385-1101(97)00034-8, 1997.

Lappalainen, J., Virtanen, E. A., Kallio, K., Junttila, S., and Viitasalo, M.: Substrate limitation of a habitat-forming genus Fucus under different water clarity scenarios in the northern Baltic Sea, Estuarine, Coast. Shelf Sci., 218, 31-38, https://doi.org/10.1016/j.ecss.2018.11.010, 2019.

Leppäranta, M. and Myrberg, K.: Physical Oceanography of the Baltic Sea, Springer-Verlag, Berlin-Heidelberg-New York, 131187, 2009.

Liu, C., Berry, P. M., Dawson, T. P., and Pearson, R. G.: Selecting thresholds of occurrence in the prediction of species distributions, Ecography, 28, 385-393, https://doi.org/10.1111/j.09067590.2005.03957.x, 2005.

Meier, H. E. M., Andersson, H. C., Eilola, K., Gustafsson, B. G., Kuznetsov, I., Müller-Karulis, B., Neumann, T., and Savchuk, O. P.: Hypoxia in future climates: A model ensemble study for the Baltic Sea, Geophys. Res. Lett., 38, 1-6, https://doi.org/10.1029/2011GL049929, 2011a.
Meier, H. E. M., Eilola, K., and Almroth, E.: Climate-related changes in marine ecosystems simulated with a 3-dimensional coupled physicalbiogeochemical model of the Baltic Sea, Clim. Res., 48, 31-55, 2011b.

Meier, H. E. M., Hordoir, R., Andersson, H. C., Dieterich, C., Eilola, K., Gustafsson, B. G., Hoglund, A., and Schimanke, S.: Modeling the combined impact of changing climate and changing nutrient loads on the Baltic Sea environment in an ensemble of transient simulations for 1961-2099, Clim. Dynam., 39, 2421-2441, https://doi.org/10.1007/s00382-012-1339-7, 2012a.

Meier, H. E. M., Muller-Karulis, B., Andersson, H. C., Dieterich, C., Eilola, K., Gustafsson, B. G., Hoglund, A., Hordoir, R., Kuznetsov, I., Neumann, T., Ranjbar, Z., Savchuk, O. P., and Schimanke, S.: Impact of Climate Change on Ecological Quality Indicators and Biogeochemical Fluxes in the Baltic Sea: A Multi-Model Ensemble Study, Ambio, 41, 558-573, https://doi.org/10.1007/s13280-012-0320-3, 2012b.

Meier, H. E. M., Andersson, H. C., Arheimer, B., Donnelly, C., Eilola, K., Gustafsson, B. G., Kotwicki, L., Neset, T.-S., Niiranen, S., Piwowarczyk, J., Savchuk, O. P., Schenk, F., Węsławski, J. M., and Zorita, E.: Ensemble Modeling of the Baltic Sea Ecosystem to Provide Scenarios for Management, Ambio, 43, 37-48, https://doi.org/10.1007/s13280-013-0475-6, 2014.

Middelburg, J. J. and Levin, L. A.: Coastal hypoxia and sediment biogeochemistry, Biogeosciences, 6, 1273-1293, https://doi.org/10.5194/bg-6-1273-2009, 2009.

Natekin, A. and Knoll, A.: Gradient boosting machines, a tutorial, Front. Neurorobotics, 7, 1-21, https://doi.org/10.3389/fnbot.2013.00021, 2013.

Nilsson, H. C. and Rosenberg, R.: Succession in marine benthic habitats and fauna in response to oxygen deficiency: analysed by sediment profile-imaging and by grab samples, Mar. Ecol. Prog. Ser., 197, 139-149, https://doi.org/10.3354/meps197139, 2000.

Norkko, J., Reed, D. C., Timmermann, K., Norkko, A., Gustafsson, B. G., Bonsdorff, E., Slomp, C. P., Carstensen, J., and Conley, D. J.: A welcome can of worms? Hypoxia mitigation by an invasive species, Glob. Change Biol., 18, 422-434, https://doi.org/10.1111/j.1365-2486.2011.02513.x, 2012.

Norkko, J., Gammal, J., Hewitt, J. E., Josefson, A. B., Carstensen, J., and Norkko, A.: Seafloor Ecosystem Function Relationships: In Situ Patterns of Change Across Gradients of Increasing Hypoxic Stress, Ecosystems, 18, 1424-1439, https://doi.org/10.1007/s10021-015-9909-2, 2015.

Pitkänen, H., Lehtoranta, J., and Räike, A.: Internal Nutrient Fluxes Counteract Decreases in External Load: The Case of the Estuarial Eastern Gulf of Finland, Baltic Sea, 30, 195-201, 2001.

Puttonen, I., Mattila, J., Jonsson, P., Karlsson, O. M., Kohonen, T., Kotilainen, A., Lukkari, K., Malmaeus, J. M., and Rydin, E.: Distribution and estimated release of sediment phosphorus in the northern Baltic Sea archipelagos, Estuarine, Coast. Shelf Sci., 145, 9-21, https://doi.org/10.1016/j.ecss.2014.04.010, 2014.

$\mathrm{R}$ Core Team: R: A language and environment for statistical computing. , R foundation for Statisticl a Computing, Vienna, Austria, available at: https://www.R-project.org/ (last access: 7 April 2019), 2018.

Rabalais, N. N., Díaz, R. J., Levin, L. A., Turner, R. E., Gilbert, D., and Zhang, J.: Dynamics and distribution of natural and human-caused hypoxia, Biogeosciences, 7, 585-619, https://doi.org/10.5194/bg-7-585-2010, 2010. 
Sappington, J. M., Longshore, K. M., and Thompson, D. B.: Quantifying Landscape Ruggedness for Animal Habitat Analysis: A Case Study Using Bighorn Sheep in the Mojave Desert, SPIE, 8 pp., 2007.

Schapire, R.: The boosting approach to machine learning - an overview, in: MSRI Workshop on Nonlinear Estimation and Classification, 2002, edited by: Denison, D., Hansen, M. H., Holmes, C., B., M., and B., Y., Springer, New York, 2003.

Scully, M. E.: Physical controls on hypoxia in Chesapeake Bay: A numerical modeling study, J. Geophys. Res.-Ocean., 118, 12391256, https://doi.org/10.1002/jgrc.20138, 2013.

Scully, M. E.: The contribution of physical processes to inter-annual variations of hypoxia in Chesapeake Bay: A 30-yr modeling study, Limnol. Oceanogr., 61, 2243-2260, https://doi.org/10.1002/lno.10372, 2016.

Stramma, L., Oschlies, A., and Schmidtko, S.: Mismatch between observed and modeled trends in dissolved upper-ocean oxygen over the last $50 \mathrm{yr}$, Biogeosciences, 9, 4045-4057, https://doi.org/10.5194/bg-9-4045-2012, 2012.

Testa, J. M., Li, Y., Lee, Y. J., Li, M., Brady, D. C., Di Toro, D. M., Kemp, W. M., and Fitzpatrick, J. J.: Quantifying the effects of nutrient loading on dissolved O-2 cycling and hypoxia in Chesapeake Bay using a coupled hydrodynamic-biogeochemical model, J. Mar. Syst., 139, 139158, https://doi.org/10.1016/j.jmarsys.2014.05.018, 2014.

Timmermann, K., Norkko, J., Janas, U., Norkko, A., Gustafsson, B. G., and Bonsdorff, E.: Modelling macrofaunal biomass in relation to hypoxia and nutrient loading, J. Mar. Syst., 105, 60-69, https://doi.org/10.1016/j.jmarsys.2012.06.001, 2012.

Vahtera, E., Conley, D. J., Gustafsson, B. G., Kuosa, H., Pitkanen, H., Savchuk, O. P., Tamminen, T., Viitasalo, M., Voss, M., Wasmund, N., and Wulff, F.: Internal ecosystem feedbacks enhance nitrogen-fixing cyanobacteria blooms and complicate management in the Baltic Sea, Ambio, 36, 186-194, https://doi.org/10.1579/00447447(2007)36[186:iefenc]2.0.co;2, 2007.

Valanko, S., Heino, J., Westerbom, M., Viitasalo, M., and Norkko, A.: Complex metacommunity structure for benthic invertebrates in a low-diversity coastal system, Ecol. Evol., 5, 5203-5215, https://doi.org/10.1002/ece3.1767, 2015.

van Helmond, N. A., Krupinski, N. B. Q., Lougheed, B. C., Obrochta, S. P., Andrén, T., and Slomp, C. P.: Seasonal hypoxia was a natural feature of the coastal zone in the Little Belt, Denmark, during the past $8 \mathrm{ka}$, Mar. Geol., 387, 45-57, 2017.
Vaquer-Sunyer, R. and Duarte, C. M.: Thresholds of hypoxia for marine biodiversity, P. Natl. Acad. Sci. USA, 105, 15452-15457, https://doi.org/10.1073/pnas.0803833105, 2008.

Villnas, A., Norkko, J., Lukkari, K., Hewitt, J., and Norkko, A.: Consequences of Increasing Hypoxic Disturbance on Benthic Communities and Ecosystem Functioning, Plos One, 7, 1-12, https://doi.org/10.1371/journal.pone.0044920, 2012.

Villnas, A., Norkko, J., Hietanen, S., Josefson, A. B., Lukkari, K., and Norkko, A.: The role of recurrent disturbances for ecosystem multifunctionality, Ecology, 94, 2275-2287, https://doi.org/10.1890/12-1716.1, 2013.

Virtanen, E. A., Viitasalo, M., Lappalainen, J., and Moilanen, A.: Evaluation, Gap Analysis, and Potential Expansion of the Finnish Marine Protected Area Network, Front. Mar. Sci., 5, 119, https://doi.org/10.3389/fmars.2018.00402, 2018.

Virtanen, E. A., Norkko, A., Nyström Sandman, A., and Viitasalo, M.: Data from: Identifying areas prone to coastal hypoxia - the role of topography, Dryad Digital Repository, https://doi.org/10.5061/dryad.cn5kh5m, 2019.

Virtasalo, J. J., Kohonen, T., Vuorinen, I., and Huttula, T.: Sea bottom anoxia in the Archipelago Sea, northern Baltic Sea - Implications for phosphorus remineralization at the sediment surface, Mar. Geol., 224, 103-122, https://doi.org/10.1016/j.margeo.2005.07.010, 2005.

Walbridge, S., Slocum, N., Pobuda, M., and Wright, D.: Unified Geomorphological Analysis Workflows with Benthic Terrain Modeler, Geosciences, 8, 1-24, 2018.

Walker, B. K., Jordan, L. K. B., and Spieler, R. E.: Relationship of Reef Fish Assemblages and Topographic Complexity on Southeastern Florida Coral Reef Habitats, SPIE, 10 pp., 2009.

Walve, J., Sandberg, M., Larsson, U., and Lännergren, C.: A Baltic Sea estuary as a phosphorus source and sink after drastic load reduction: seasonal and long-term mass balances for the Stockholm inner archipelago for 1968-2015, Biogeosciences, 15, 30033025, https://doi.org/10.5194/bg-15-3003-2018, 2018.

Weiss, A. D.: Topographic position and landforms analysis, In Poster presented at the Esri User Conference, San Diego, CA, USA, http://www.jennessent.com/downloads/ tpi-poster-tnc_18x22.pdf (last access: 17 January 2019), 2001.

WFD: Water Framework Directive, Common Implementation, 2000. 